\title{
Microbiology aspect of wound infection: in-vitro test for efficacy of hydrophobic dressing in microorganism binding
}

\author{
Yeva Rosana, Beti E. Dewi, Conny R. Tjampakasari \\ Dept. of Microbiology, Faculty of Medicine, University of Indonesia, Jakarta
}

\begin{abstract}
Abstrak
Tujuan Menguji secara in vitro kemampuan kasa steril hidrofobik Cutimed ${ }^{\circledR}$ Sorbact ${ }^{\circledR}$ untuk mengikat mikroorganisme multiresisten penyebab luka, methicillin-resistant Staphylococcus aureus (MRSA) dan Pseudomonas aeruginosa.

Metode Desain penelitian ini adalah potong lintang. Penelitian dilakukan di Departemen Mikrobiologi, Fakultas Kedokteran, Universitas Indonesia pada bulan Januari 2009. Pengujian kasa steril hidrofobik untuk mengikat mikroorganisme secara in-vitro dilakukan dengan cara menghitung jumlah MRSA dan Pseudomonas aeruginosa yang terikat pada $1 \mathrm{~cm}$ persegi selapis kasa steril hidrofobik Cutimed ${ }^{\circledR}$ Sorbact ${ }^{\circledR}$. Setiap pengujian dilakukan secara triplo pada waktu paparan 0,5, 1, 5, 10, dan 30 menit serta 1, 2, 3, dan 4 jam. Untuk melihat kemampuan daya ikat kasa steril hidrofobik terhadap mikroorganisme uji, sebagai pembanding dilakukan juga uji daya ikat secara in vitro dari kasa steril konvensional terhadap mikroorganisme uji, pada waktu paparan 0,5 menit dan 2 jam.
\end{abstract}

Hasil Kasa steril hidrofobik Cutimed ${ }^{\circledR}$ Sorbact ${ }^{\circledR}$ mempunyai kemampuan untuk mengikat MRSA dan Pseudomonas aeruginosa mulai dari waktu paparan 0,5 menit dan mencapai maksimal pengikatan pada paparan selama 2 jam. Dibandingkan dengan kasa steril konvensional, kasa steril hidrofobik Cutimed ${ }^{\circledR}$ Sorbact ${ }^{\circledR}$ mempunyai kemampuan yang lebih kuat untuk mengikat MRSA dan Pseudomonas aeruginosa.

Kesimpulan Kasa steril hidrofobik Cutimed ${ }^{\circledR}$ Sorbact ${ }^{\circledR}$ mempunyai kemampuan mengikat MRSA dan Pseudomonas aeruginosa yang lebih baik daripada kasa steril konvensional. (Med J Indones 2009; 18: 155-60)

\begin{abstract}
Aim To do in vitro test to assess the efficacy of hydrophobic dressing Cutimed $^{\circledR}$ Sorbact $^{\mathbb{R}}$ to bind multiresistant bacteria that caused wound infection, the methicillin-resistant Staphylococcus aureus (MRSA) and Pseudomonas aeruginosa.

Method This was a cross sectional study that was conducted in the Department of Microbiology, Faculty of Medicine, University of Indonesia, on January 2009. In-vitro testing of sterile hydrophobic dressing to bind microorganisms was conducted by counting MRSA and Pseudomonas aeruginosa that were bound to 1 square centimetre of single layer sterile hydrophobic dressing $\left(\right.$ Cutimed $^{\mathbb{R}}$ Sorbact $\left.^{\mathbb{R}}\right)$. Every test was done in triplicate at $0.5,1,5,10,30$ minutes, 1 , 2,3 , and 4 hours. To compare the hydrophobic dressing capability to bind microorganisms, in vitro testing of sterile conventional dressing to bind microorganisms on 0.5 minutes and 2 hours was done.

Result The binding capacity of sterile hydrophobic dressing began at 0.5 minutes and teached a maximum at 2 hours. Compared with conventional dressing, sterile hydrophobic dressing had more binding capability to MRSA and Pseudomonas aeruginosa.
\end{abstract}

Conclusion Hydrophobic dressing $\left(\right.$ Cutimed $^{\circledR}$ Sorbact $^{\circledR}$ ) had a higher capability to bind MRSA and Pseudomonas aeruginosa compared to conventional dressing. (Med J Indones 2009; 18: 155-60)

Key words: hydrophobicity, MRSA, Pseudomonas aeruginosa

Every wound, even an aseptic surgical wound, is contaminated with microorganisms. The wound is infected when bacteria penetrate deeper into the wound, multiply, damage the tissue with their toxins or induce symptoms of inflammation. ${ }^{1,2}$

Initial wound treatment usually comprises mechanical cleansing with water, buffer solutions or disinfectants to remove bacteria and debris. ${ }^{3,4}$ This is of paramount importance since debris impedes wound healing.
Systemic administration of antibiotics is indicated if signs of infection are present or if bacteria have spread to the blood stream. Decades of experience have shown that it is often advisable to avoid the use of local antibiotics because of the risk of antibiotic resistance. Significant problems are now being encountered with multiple antibiotic resistant wound pathogens such as methicillin-resistant Staphylococcus aureus (MRSA) and Pseudomonas aeruginosa. ${ }^{5,6,7}$ 
Sterile hydrophobic dressing is a unique mode of action to bind and inactivate microorganisms in the area of wound infection by hydrophobic interaction without using any antiseptic or antibiotic agents. A basic physical principle of hydrophobic interaction is two hydrophobic (water repellent) particles bind to each other with help from the surrounding water molecules that form a circle around the particles - like a jacket - and hold them together., ${ }^{2,8}$

With this mode of action no substances are released from the dressing into the wound, and the underlying mechanism is purely physical. The bacteria binding effect is of particular interest because it requires no systemic or local antimicrobial agents. ${ }^{9}$ When bacteria or other microorganisms contact the wound dressing in a moist environment, they are bound to the dressing surface and are removed from the wound when the dressing is changed.

This study aimed to do in vitro test to assess the efficacy of hydrophobic dressing Cutimed ${ }^{\mathbb{B}}$ Sorbact $^{\mathbb{B}}$ to bind multiresistant bacteria, which cause wound infection, the MRSA and Pseudomonas aeruginosa. In addition, the binding capacity of hydrophobic dressing Cutimed ${ }^{\mathbb{B}}$ Sorbact $^{\mathbb{B}}$ was compared with conventional dressing.

\section{METHODS}

This was a cross section study that was done in the Department of Microbiology, Faculty of Medicine University of Indonesia, on January 2009. Methicillin-resistant Staphylococcus aureus and Pseudomonas aeruginosa were cultured on nutrient agar and harvested after 18 to 24 hours of incubation. The bacterial concentration was adjusted to $0.5 \mathrm{MacFarland}\left(1.5 \times 10^{8} \mathrm{CFU} / \mathrm{ml}\right)$ by Nephlometer equipment, and immediately used for the binding assays.

\section{Binding Assays}

The wound dressing materials i.e. hydrophobic dressing Cutimed ${ }^{\circledR}$ Sorbact $^{\circledR}$ (acetate fabric) and conventional dressing were cut into $1 \mathrm{~cm}^{2}$ sheets under sterile condition and were incubated with $1 \mathrm{ml}$ of bacterial solution at various incubation time $(0.5,1,5,10,30$ minutes, 1, 2, 3, and 4 hours respectively for the hydrophobic dressing. For conventional dressing, we just used 0.5 minute and 120 minutes of incubation time. The experiment was done in triplicate $(\mathrm{n}=3)$.
After incubation, the dressings were washed three times for 5 minutes each with $0.07 \mathrm{M}$ phosphate buffered saline (PBS), $\mathrm{pH} 7.2$, and placed in nutrient broth. Then the nutrient broth were incubated at $35-37^{\circ} \mathrm{C}$ for 18 to 24 hours.

The number of bound bacteria to hydrophobic dressing Cutimed $^{\circledR}$ Sorbact $^{\circledR}$ (acetate fabric) and conventional dressing were determined by Nephlometer equipment.

\section{Data Analysis}

The data were noted and expressed as means \pm SD. The difference between hydrophobic and conventional dressing in term of the number of bound bacteria at 0.5 minute and 120 minutes incubation time was determined by Student's t-tests. Differences were considered to be significant when $P$-value was less than 0.05 .

\section{RESULTS}

\section{Hydrophobic dressing Cutimed ${ }^{\circledR}$ Sorbact $^{\circledR}$ binding assays}

\section{Methicillin-resistant Staphylococcus aureus}

In-vitro binding assay of hydrophobic dressing Cutimed ${ }^{\circledR}$ Sorbact ${ }^{\mathbb{R}}$ to MRSA at various incubation time were showed in Figure 1. Using this method, the bound MRSA to $1 \mathrm{~cm}^{2}$ of the hydrophobic dressing were $4.3 \times 10^{8} \pm 0.2 \times 10^{8}$ at 0.5 minute incubation. Incubation period of $0.5,1,5,10$, 30 and 60 minutes showed variation in bound MRSA that was not significant different $(P>0.05)$.

Binding of MRSA to the hydrophobic dressing reached a maximum at 120 minutes of incubation $\left(6.6 \times 10^{8} \pm 0.1\right.$ $\left.\mathrm{x} 10^{8} \mathrm{CFU} / \mathrm{ml}\right)$ and showed significant difference compared to 30 second incubation time $(P<0.05)$. Compared with 2 hours, the 3 and 4 hour incubation showed reduction in the number of bound MRSA to the hydrophobic dressing. The number of MRSA binding to the hydrophobic dressing at 3 and 4 hours were not significantly different with 0.5 minute incubation time $(P>0.05)$.

\section{Pseudomonas aeruginosa}

The results of the binding assays of hydrophobic dressing Cutimed ${ }^{\mathbb{}}$ Sorbact $^{\mathbb{}}$ to Pseudomonas aeruginosa were similar with those of MRSA. Pseudomonas aeruginosa bound to $1 \mathrm{~cm} 2$ of the hydrophobic dressing at $0.5 \mathrm{mi}-$ nute of incubation was $2.3 \times 10^{8} \pm 0.6 \times 10^{8}$ (Figure 2). 


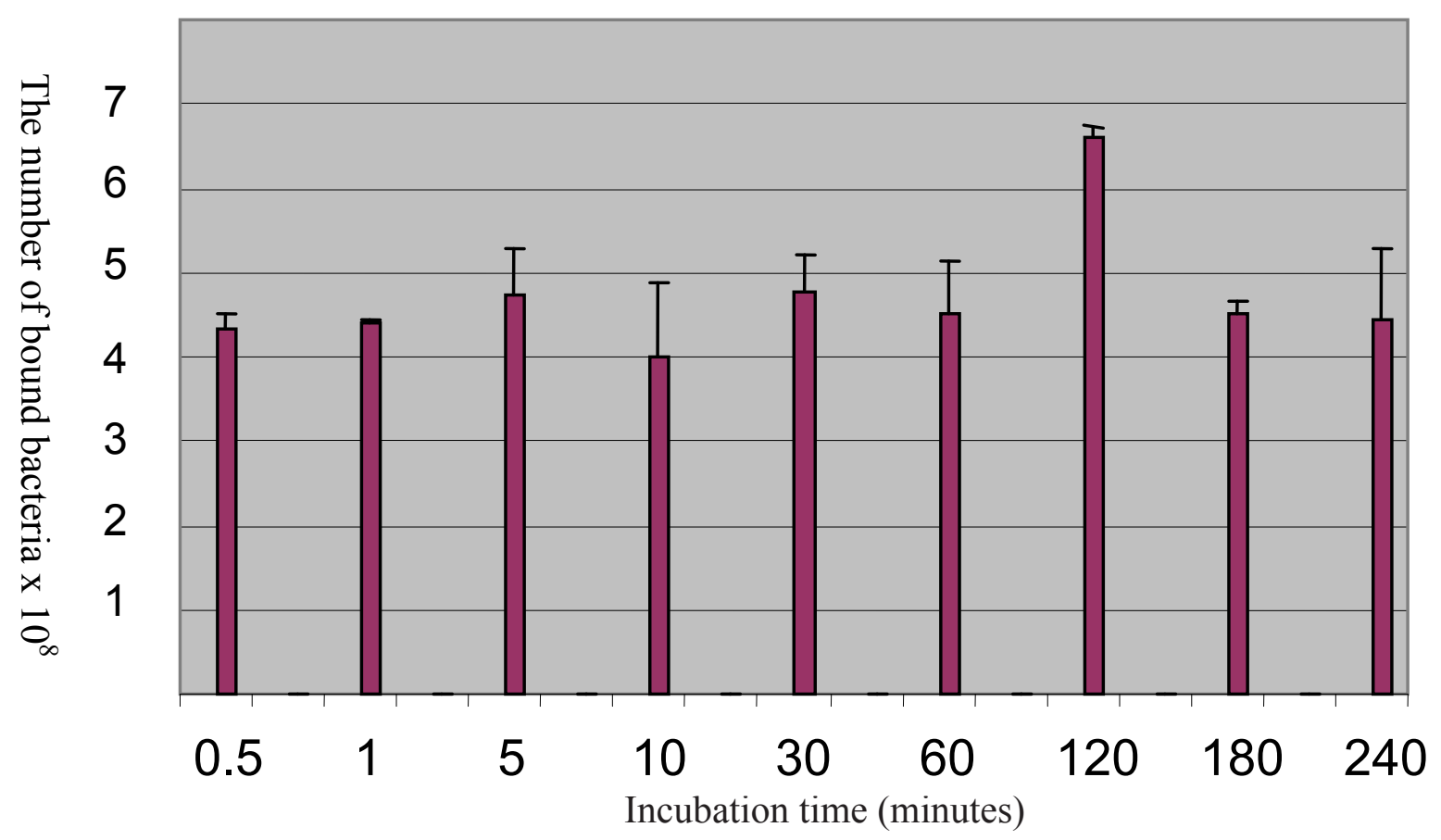

Figure 1. The number of MRSA bound to hydrophobic dressing Cutimed ${ }^{\circledR}$ Sorbact ${ }^{\circledR}$ at various incubation time.

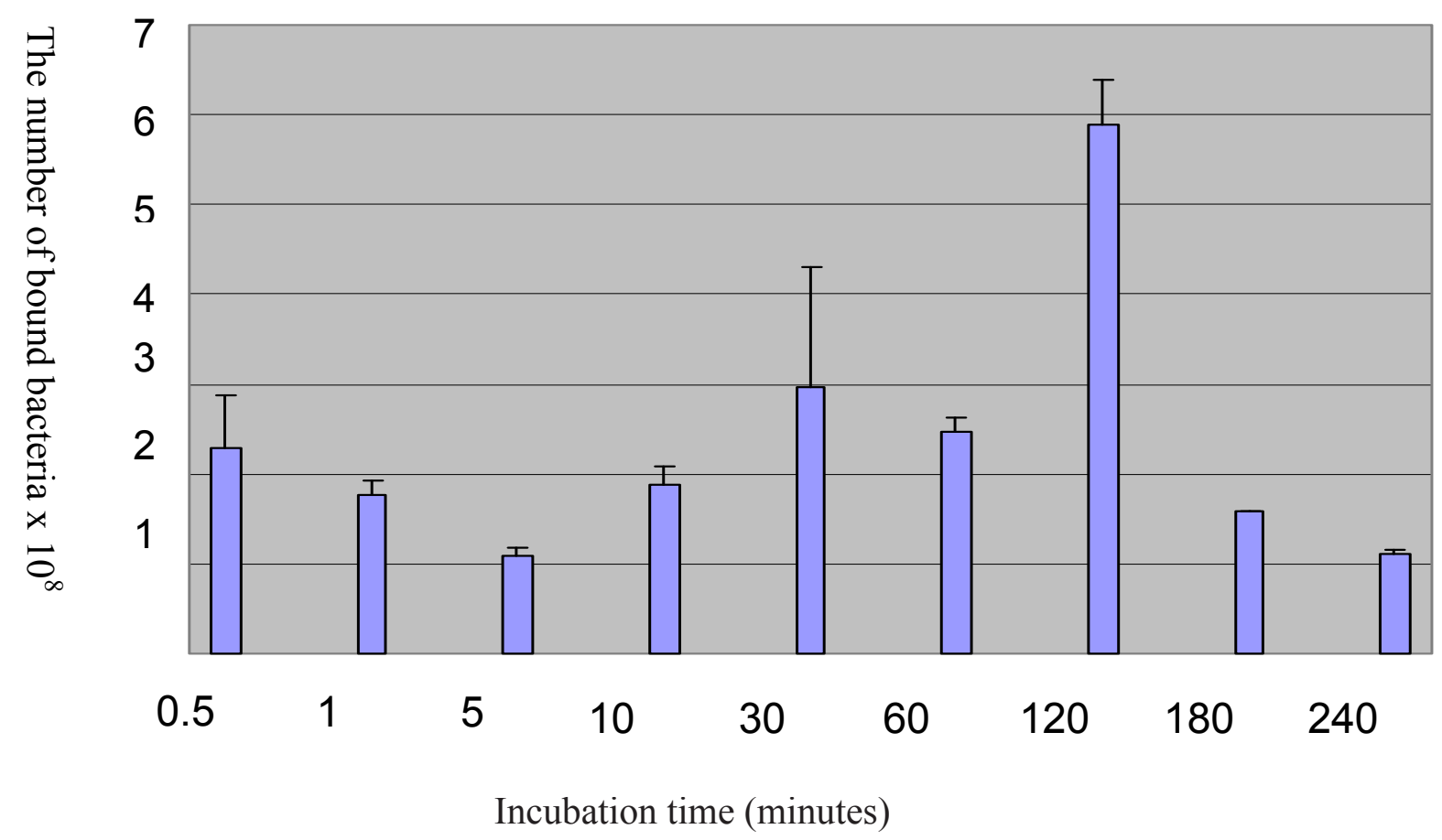

Figure 2. The number of Pseudomonas aeruginosa bound to hydrophobic dressing Cutimed ${ }^{\mathbb{B}}$ Sorbact ${ }^{\mathbb{B}}$ at various incubation time. 
The bound Pseudomonas aeruginosa was decreased after 1 and 5 minutes, but increased after 30 minutes of incubation time. The number of Pseudomonas aeruginosa binding to the hydrophobic dressing at 30 seconds to 60 minutes varied, but do not differ significantly $(P>0.05)$.

The bound Pseudomonas aeruginosa reached a maximum $\left(5.9 \times 10^{8} \pm 0.5 \times 10^{8}\right)$ at 120 minutes of incubation $(P<0.05)$, but longer incubation for 3 and 4 hours reduced the number of bound Pseudomonas aeruginosa to the hydrophobic dressing.

\section{Comparison of binding capacity of hydrophobic dressing Cutimed $^{\circledR}$ Sorbact $^{\circledR}$ compared to conventional dressing}

Figure 3 and 4 showed that hydrophobic dressing $\mathrm{Cu}-$ timed ${ }^{\circledR}$ Sorbact ${ }^{\circledR}$ could bind bacteria more than conventional dressing at 0.5 minute incubation time $(P<0.01)$. Incubation at 120 minutes showed the same trend for MRSA and Pseudomonas aeruginosa binding.

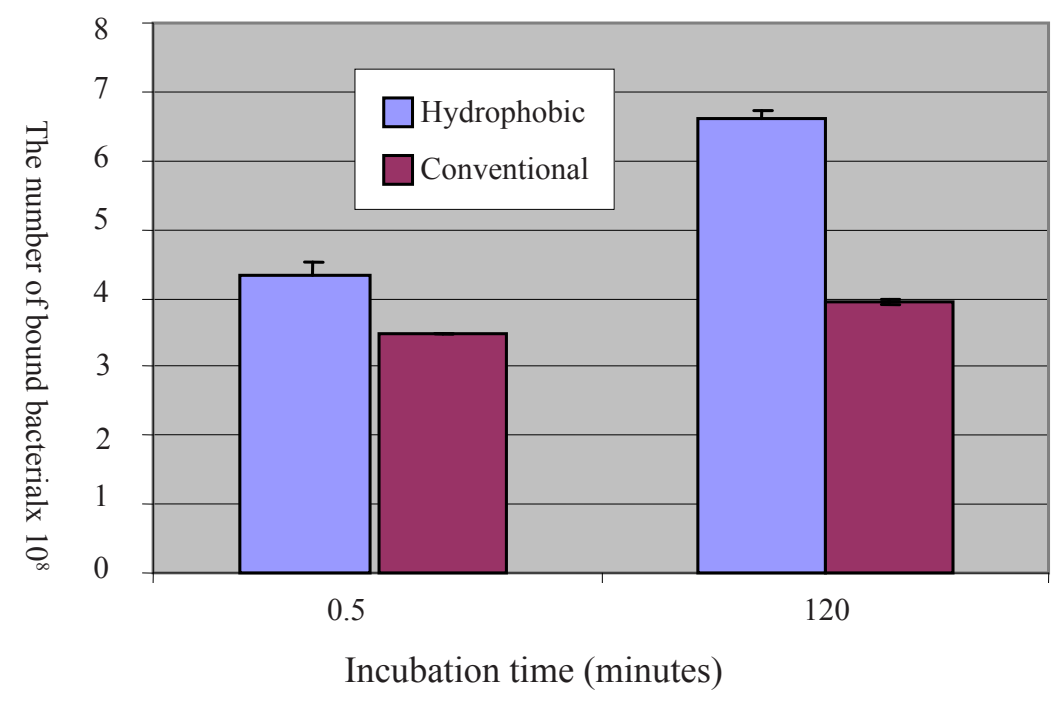

Figure 3. The number of MRSA bound to hydrophobic dressing Cutimed ${ }^{\circledR}$ Sorbact ${ }^{\circledR}$ and conventional dressing at 0.5 minute and 120 minutes incubation time.

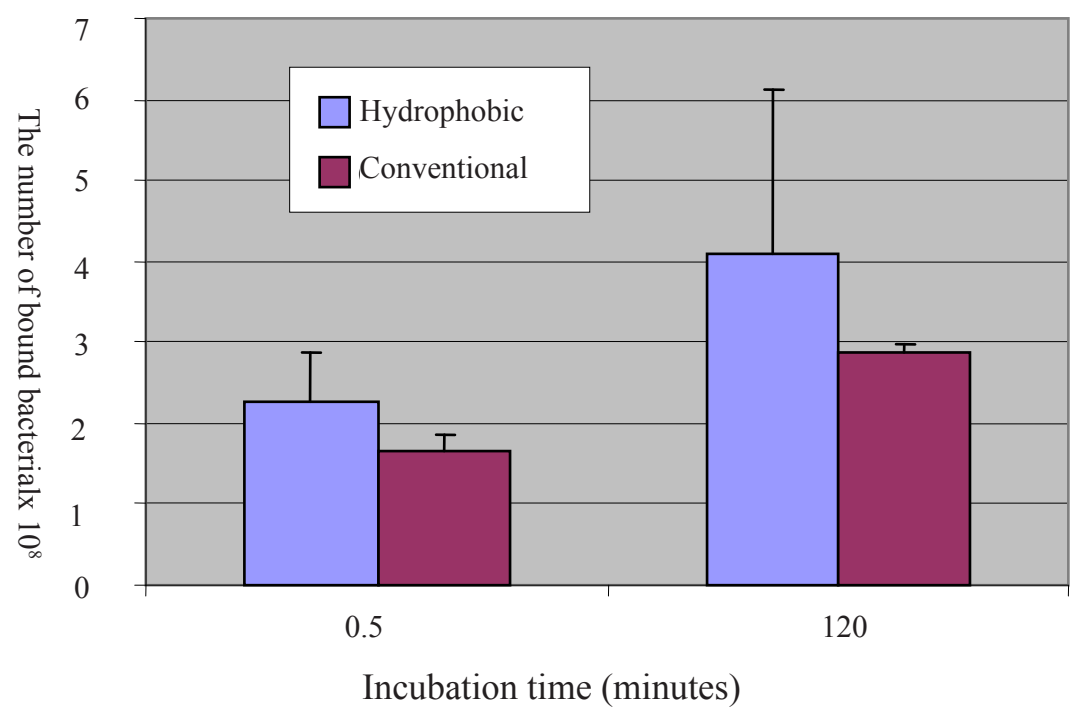

Figure 4. The number of Pseudomonas aeruginosa bound to hydrophobic dressing Cutimed ${ }^{\circledR}$ Sorbact $\AA^{\circledR}$ and conventional dressing at 0.5 minute and 120 minutes incubation time. 


\section{DISCUSSION}

Wound infections are usually caused by wound pathogens such as Staphylococcus aureus and group A Streptococci (GAS), Pseudomonas aeruginosa, members of the Enterobacteriaceae, Enterococci, and other Streptococci families and anaerobic microbes. ${ }^{10,11}$ Chronic infections are often of polymicrobial origin and fungi such as Candida albicans are commonly isolated. ${ }^{12-14}$

In wound infections, several types of bacteria are usually simultaneously active. The appearance of an infection looks either as a primary pyogenic wound infection that is caused by pus forming microorganisms, putrefactive bacteria wound infection induced, or anaerobic wound infection that is caused by anaerobes. ${ }^{1}$

Numerous studies have shown that bacteria generally express story cell surface hydrophobicity (CSH). This property is of vital importance for microorganisms since, for instance, it enables them to bind to nutrient substrate surfaces. Several structures which render the cell surface hydrophobic have been identified such $\mathrm{a}=\mathrm{s}$ the hair-like protein appendages, the fimbriae, which mediate adhesion. Further hydrophobic structures are lipoteichoic acid in the cell wall of gram-positive bacteria and proteins on C. albicans that is called the "hydrophobins" ${ }^{15}$

The initial phase of infections of the skin and mucosal surfaces is characterized by microbial adhesion to traumatized tissues that is mediated by hydrophobic interactions between microbes and host tissue. The wound environment enhances expression of CSH by colonising microbes. Wound pathogenic bacteria and fungi express cell surface hydrophobicity, and the more virulent will be the more hydrophobic.

Since most pathogenic microorganisms that impair wound healing have hydrophobic properties, it is useful to use hydrophobic interaction principle to remove them. In other words, only microbial cells expressing CSH will be removed; hydrophilic cell surface microbes expressing is left behind.

In addition, to determine the efficacy of hydrophobic dressing that has a basic physicochemical property to bind CSH microbes expressing, we compared hydrophobic dressing Cutimed $^{\circledR}$ Sorbact $^{\circledR}$ with conventional dressing in their capacity MRSA and Pseudomonas aeruginosa. Bound MRSA and Pseudomonas aeruginosa at the hydrophobic dressing was showed at early incubation time ( 0.5 minute). This result showed that the hydrophobic dressing is capable to bind bacteria in a short time after incubation. The peak of the binding capacity was showed at 120 minutes of incubation time. This result was similar with the result of Ljungh et al in Journal Wound Care 2006. Compared to conventional dressing, the capacity of the hydrophobic dressing to bind MRSA and Pseudomonas aeruginosa was higher.

The possibility of bound microorganisms to replicate was, tested by calculating the number of bound bacteria that was released by $2.5 \%$ trichloroacetic acid (TCA). We applied the method but it was difficult to release all of bound bacteria from the hydrophobic dressing. Ljungh et al in Journal Wound Care 2006 reported that microbes multiply to a very low extent after binding to the hydrophobic dressing.

Microorganisms that express cell surface hydrophobicity $(\mathrm{CSH})$ are water repellent and are likely to bind to a hydrophobic dressing. Cutimed ${ }^{\circledR}$ Sorbact $^{\mathbb{R}}$ is a hydrophobic agent coated dressing that has a basic physicochemical property to bind CSH expressing microbes, and to remove them from wounds. Use of the dressing without antibiotic may reduce, but not eliminate the microbial load in a wound, and may activate or support the natural wound healing process.

The hydrophobic dressing should be used in wounds with high and medium exudate level as hydrophobic interaction is most effective in a moist environment. The microorganisms multiply to quite a low extent when absorbed in the dressing, and therefore may not produce extracellular toxins and enzyme.

Inconclusion, Hydrophobic dressing $\left(\right.$ Cutimed $^{\circledR}$ Sorbact $\left.^{\circledR}\right)$ had a higher capability to bind MRSA and Pseudomonas aeruginosa compared to conventional dressing.

\section{Acknowledgment}

This study is funded by PT. BSN Medical Indonesia. We thanks to Mrs. Lindah, Mr. Syarief, Mrs. Shinta, Mrs. Lina Isjah, Mr. Ayub, Mrs. Mariah, Mrs. Dahlia and team of Microbiology FKUI for their technical assistance and cooperation.

\section{References}

1. von Hallern B, Doerk M R, von der Weth A. Removal of wound bacteria from infected and colonized wounds with Cutisorb Sorbact. In: BSN Medical. Medizin \& Praxis Spezial, Disturbances of Wound Healing. Stade; Verlag für Medizinische Publikationen; 2004. p.61-9. 
2. Ljungh A, WadströmT. A new antibacterial wound dressing without chemically active agent for the care of infected wounds. In: BSN Medical. Medizin \& Praxis Spezial, Infected Wound. Stade: Verlag für Medizinische Publikationen; 2005. p.8-11.

3. Nichols RL . Preventing surgical site infections: A surgeons perspective. Journal of Emerg Infect Dis. 2001; 7: 220-4.

4. Larson E. Hygiene of the skin: When is clean too clean? Emerg Infect Dis. 2001; 7: 225-30.

5. Claesson M, Bulgakow B, Blomqvist P, Andersson K. A promising alternative in the treatment of dermal fungal infections. In: BSN Medical. Medizin \& Praxis Spezial, Ulcus cruris. Stade: Verlag für Medizinische Publikationen; 2006. p.55-6

6. Kammerlander G, Locherer E, Süss-Burghart A, von Hallern B, Wipplinger P. Non-medicated wound dressing as an antimicrobial alternative in wound management. Die Schwester Der Pfleger. 2007; 46: 84-7.

7. Tenover FC, Biddle JW, Lancaster MV. Increasing resistance to vancomycin and other glycopeptides in Staphylococcus aureus. Emerg Infect Dis. 2001; 7: 327-31.

8. von Hallern B. Cutisorb ${ }^{\circledR}$ Sorbact $\AA$-Nonpharmacologic antibacterial therapy in traumatology and surgery. In: BSN Medical. Medizin \& Praxis Spezial, Postoperative Wound Dehis- cence. Stade: Verlag für Medizinische Publikationen; 2004. p.14-20.

9. Ljungh A, Yanagisawa N, Wadström T. Using the principle of hydrophobic interaction to bind and remove wound bacteria. Journal of Wound Care. 2006; 15(4): 175-80.

10. Bowler PG, Davies B.J. The Microbiology of acute and chronic wounds. Wounds. 1999; 11: 2-8.

11. Davies CE, Hill KE, Wilson MJ. Use of 16 S ribosomal DNA PCR and denaturing gradient gel electrophoresis for analysis of the microfloras of healing and nonhealing chronic venous leg ulcers. J Clin Microbiol. 2004; 42: 3549-57.

12. Howell-Jones RS, Wilson MJ, Hill KE. A review of the microbiology, antibiotic usage and resistance in chronic wounds. J Antimicrob Chemother. 2005; 55: 143-9.

13. Faergemann, J. Atopic dermatitis and fungi.Clin Microbiol Rev.2002;15:545-63.

14. Stephens P, Wall IB,Wilson MJ. Anaerobic cocci populating the deep tissues of chronic wounds impair cellular wound healing responses in vitro. Br J Dermatol. 2003; 148: 456-66.

15. von Hallern B, Lang F. Has Cutisorb ${ }^{\circledR}$ Sorbact ${ }^{\circledR}$ proved its practical value as an antibacterial dressing? In: BSN Medical. Medizin \& Praxis Spezial, Infected Wound. Stade: Verlag für Medizinische Publikationen; 2005. p.2-7. 